\title{
Om nye artikler høsten 2020 og redaktørskifte i ADNO
}

Høstens utgave av Acta Didactica Norden inneholder syv vitenskapelige artikler og to bokanmeldelser. Det er hyggelig å omsider kunne publisere bokanmeldelser igjen. De gir nyttige bidrag til det aktuelle fagfeltet, men ADNO har de senere år mottatt få eller ingen bidrag innen denne sjangeren. Nå ser det ut til at trenden er i ferd med å snu, og flere bokanmeldelser er i prosess.

Artiklene i inneværende utgave er skrevet på norsk, svensk, dansk og engelsk og dekker emner innen matematikkfaget, samfunnsfag, morsmålsfaget og engelskfaget, samt temaer som muntlig eksamen og nyutdannede læreres utfordringer.

Valenta \& Enge gjør en læreplananalyse av den nye læreplanen i matematikk for norsk grunnskole. De fokuserer på hvordan arbeid med matematisk gyldig argumentasjon ('bevis') kommer til syne i planen på ulike klassetrinn. Hensikten er å undersøke hvordan den nye læreplanen legger opp til utvikling av elevers kompetanser innen matematisk resonnering, argumentasjon og bevis i løpet av grunnskolen.

Olovssons artikkel tar også for seg en ny læreplan, nærmere bestemt den nye læreplanen for samfunnsfag i svensk grunnskole (trinn 4-6). Denne planen gir de ulike disiplinene - som geografi, historie, religion og samfunnskunnskap - en mer fremtredende rolle enn i tidligere læreplan. Olovsson undersøker hvilke muligheter og utfordringer lærerne ser i den nye planen når det gjelder å tilby undervisning som går på tvers av de ulike disiplinene.

Myren-Svelstad diskuterer i sin artikkel om morsmålsfaget premissene for læreres valg av skjønnlitterære tekster til bruk i undervisningen. Han problematiserer de to kriteriene det ofte vises til - kvalitet og representativitet - og nyanserer debatten «for eller imot» en fast kanon. Med utgangspunkt i postkritisk teori foreslår han tre alternative innganger til valg av skjønnlitteratur i morsmålsfaget.

De to artiklene fra engelskfaget omhandler begge studier der elever i norsk videregående skole er deltakere. Skjelde \& Coxhead undersøker ved hjelp av vokabulartester i hvilken grad elevene mestrer engelsk akademisk ordforråd - et felt de må mestre for å være forberedt til høyere utdanning. Videre undersøker de sammenhengen mellom vokabularforståelse og oppnådd karakter i engelskfaget. Saliu-Abdulahi \& Hellekjær bruker spørreskjema for å innhente informasjon om hvordan elever opplever og følger opp tilbakemeldinger de får i engelskfagets skriveundervisning. Med utgangspunkt i resultatene diskuterer de hvordan det kan legges til rette for mer fruktbare vurderingspraksiser. 
Isager gir i sin artikkel et kritisk blikk på muntlig eksamen i dansk videregående skole (gymnasium). Ved hjelp av anerkjent vurderingsteori analyserer hun sentrale styringsdokumenter, læreplaner og veiledninger for å undersøke hva som kommuniseres om testens konstrukt og hvilke slutninger som kan trekkes når det gjelder testens validitet.

Amdal \& Willbergh skriver om nyutdannede læreres opplevelse av overgangen fra utdanning og lærerstudenttilværelse til læreryrket og selvstendig profesjonsutøvelse. I stedet for å fokusere utelukkende på utfordringene i overgangsfasen, benytter Amdal \& Willbergh hermeneutisk danningsteori til å løfte fram overgangen som en fruktbar utviklingsprosess der lærernes profesjonelle utvikling initieres.

I tillegg til disse syv artiklene, som inngår i høstens ordinære nummer av Acta Didactica Norden (ADNO 14/3), har tidsskriftet i høst publisert et temanummer om kontroversielle spørsmål i utdanningen (ADNO 14/4), redigert av en gjesteredaksjon fra Umeå universitet i Sverige. Flere temanumre er i arbeid, hvorav de fleste har kommet til i et samarbeid på tvers av nordiske landegrenser. Redaksjonen tar fortsatt imot forslag til temanumre, gjerne fra tverrnordiske gjesteredaksjoner. Pågangen er stor, så hvis man ønsker å foreslå et temanummer, bør man være tidlig ute og levere et velbegrunnet og gjennomarbeidet forslag.

Nå som vi går inn i et nytt år, vil jeg samtidig takke for meg som redaktør i ADNO. Jeg begynte som ansvarlig redaktør i ADNO ved inngangen til 2017, og redaktørarbeidet har vært både lærerikt og spennende. Det har også vært fire begivenhetsrike år for ADNO. Tidsskriftet, som i utgangspunktet var nasjonalt, etablerte seg som et nordisk tidsskrift, og byttet som kjent i den forbindelse navn fra Acta Didactica Norge til Acta Didactica Norden. Det ble indeksert i Scopus og fikk nye nettsider. En rekke nye redaksjons- og redaksjonsrådmedlemmer og fagfeller fra flere nordiske land ble vervet. Gjennom alle år har det vært en jevn økning i innsendte artikler, den senere tid også en økt tilstrømming av artikler fra Sverige og Danmark. Interessen for temanumre har også vært jevnt økende. Denne positive utviklingen hadde ikke vært mulig uten alt arbeidet som legges i ADNO fra alle de dedikerte ressurspersonene som på ulike måter er knyttet til tidsskriftet. Jeg ønsker derfor å takke redaksjonen med områderedaktører, layoutredaktør og korrekturleser, for det gode samarbeidet vi har hatt i disse årene og for den verdifulle innsatsen de gjør for tidsskriftet. Jeg vil også takke gjesteredaksjonene for temanumre for det arbeidet de har gjort, samt alle redaksjonsrådsmedlemmer for deres velvilje til å stille opp som ressurspersoner for ADNO. I tillegg vil jeg takke alle de anonyme fagfellene som har bidratt med viktig kvalitetssikring av innhold som publiseres i tidsskriftet. Takk også til FrittUiO, som drifter publiseringsløsningen og yter uvurderlig teknisk støtte. Til slutt vil jeg takke 
forfattere og lesere, som med sin aktive bruk av tidsskriftet bidrar til et aktuelt og dynamisk tidsskrift.

F.o.m. januar 2021 overtar Kirsten Marie Hartvigsen det redaksjonelle ansvaret for tidsskriftet. Jeg er sikker på at ADNO er i gode hender hos henne og ønsker henne og resten av redaksjonen lykke til med det videre arbeidet.

Oslo, januar 2021

Eva Thue Vold 